\title{
Effect of Visfatin on the Structure and Immune Levels in the Small Intestine of LPS-Induced Rats
}

\author{
Efecto de la Visfatina sobre la Estructura y los Niveles de Inmunidad \\ en el Intestino Delgado de Ratas Inducidas por Lipopolisacáridos
}

Ying Zhou*; Lu Cui*; Huairui Yuan*; Ke Xiao*; Faheem Ahmed Khan*; Liang Guo*; Zhi Yang* \& Hui Song*

ZHOU, Y.; CUI, L.; YUN, H.; XIO, K.; KAHN, F. A.; GUO, L.; YANG, Z. \& SONG, H. Effect of visfatin on the structure and immune levels in the small intestine of LPS-induced rats. Int. J. Morphol., 33(4):1502-1509, 2015.

SUMMARY: This study investigated the effects of visfatin on the structure and the immunity levels in the small intestine of LPS-induced rats. Forty Wistar male and female SPF rats were randomly and equally divided into four groups: the saline (control), vistfatin, lipopolysaccharide (LPS), and visfatin+LPS co-stimulated. The functions of visfatin in the intestinal mucosal immunity were investigated by examining the variation of tissue structure, inflammation and immunity-related proteins in the intestine of immunologically stressed rats using HE staining, ELISA, immunohistochemistry and Western Blot. The results showed that, when compared with the control group, the visfatin-treated group showed a decrease in the intestinal villus height and width, and a significant increase in the levels of IL-6 and TNF- $\partial$ as well as Immunoglobulin A (IgA) positive cells. Additionally, when compared with the LPS-treated group, the visfatin+LPS co-stimulated group showed a decrease in the villus height and width as well as the levels of IL- 6 and TNF- $\partial$, and an increase in IgA levels, implying a shrinking response to LPS injection. All the results suggest that, under normal physiological conditions, visfatin disturbs the body's homeostasis and causes intestinal villus atrophy by increasing IgA expression. While under immune response conditions, LPS acts as an exogenous antigen to promote visfatin against LPS-induced inflammation by decreasing the expression of $\operatorname{IgA}$. Under immune stress conditions, visfatin as an exogenous stimulus promotes the immune response by regulating the protein levels of IL-6, TNF- $\partial$ and IgA.

KEY WORDS: Visfatin; Intestinal mucosa; LPS-induced rats; IgA; Inflammatory factor.

\section{INTRODUCTION}

Intestinal mucosal immune system has an important role in maintaining the homeostasis of the body by ensuring its immune response to pathogens and enabling the body to keep a dynamic balance between the internal and external environments (Didierlaurent et al., 2002; MacDonald, 2003; Shaykhiev \& Bals, 2007). A better understanding of the mechanism of intestinal mucosal immune response is of important significance for the prevention of intestinal diseases. Currently, the mechanism underlying intestinal mucosal immune system has attracted more and more attention among researchers, but the mechanism by which the intestinal mucosal immunity is regulated by different cytokines is still poorly understood. Visfatin, a kind of adipose cytokine, was found in 2005 . It can promote the synthesis and accumulation of fat tissues, and regulate lipid and glucose metabolism (Brentano et al., 2007; Gao et al.,
2011; Goujon et al., 1996; Moschen et al., 2010). As visfatin plays an important role in diabetes, immune response and inflammation, its mechanism has been attaining more importance (Eker et al., 2010; Moschen et al., 2007; Ognjanovic \& Bryant-Greenwood, 2002; Stephens \& VidalPuig, 2006). It also performs many functions, including enhanced cell proliferation and biosynthesis of nicotinamide mononucleotides and dinucleotides (Skoczen et al., 2014). To date, the study of visfatin is still in its infancy and the mechanism of visfatin, as a peptide, in the intestinal mucosa is yet not completely understood.

In the present study, we investigated the regulation of visfatin on the structure and the immune levels in the small intestine of LPS-induced rats by exploring its mechanism in the mucosal immune system.

\footnotetext{
* College of Animal Science and Technology, Huazhong Agricultural University, Wuhan, China.

Ying Zhou \& Lu Cui contributed equally in this article.
} 


\section{MATERIAL AND METHOD}

Reagent. Rat visfatin was purchased from Adipo Bioscience. LPS (O111: B4) was obtained from Sigma (St Louis, MO, USA). The cytokines including IL-6, and TNF- $\partial$ were quantified using rat double-antibody sandwich indirect ELISA kits (Multisciences, China). The antibodies for GAPDH, and IgA were obtained from Beijing Biosynthesis Biotechnology (Beijing, China).

Animals. Eight-week-old SPF Wistar Rats, 200 \pm 20 g, were purchased from Hubei Provincial Center for Disease Control and Prevention. Forty rats (20 male and 20 female) were randomly divided with equal sex ratio into 4 groups: the saline (control), vistfatin, lipopolysaccharide (LPS), and visfatin+LPS co-stimulated groups. All rats were individually housed in cages, with temperature-controlled $\left(23-25^{\circ} \mathrm{C}\right)$ and maintained on a $12 \mathrm{~h}$ light/dark cycle. Water and food were provided ad libitum. The control group received one daily injection of isotonic saline $(0.5 \mathrm{ml}, \mathrm{i} . \mathrm{v}$. $)$ for 7 days. The visfatin group received one daily injection of visfatin $(50 \mu \mathrm{g} / \mathrm{kg}$ bw i.v.) for 7 days. The LPS group received one daily injection of isotonic saline $(0.5 \mathrm{ml}, \mathrm{i} . \mathrm{v}$. $)$ for 7 days and one injection of LPS (2.5 mg/kg bw i.v.) 6 hours before sacrifice. The visfatin+LPS co-stimulated group received one daily injection of visfatin $(50 \mu \mathrm{g} / \mathrm{kg}$ bw i.v. $)$ for 7 days, followed by a single-dose injection of LPS (2.5 $\mathrm{mg} / \mathrm{kg}$ bw i.v.) by caudal vein 6 hours before sacrifice. Six hours after the last treatment, all rats were anesthetized with i.v. injection of $1 \%$ pentobarbital $(25 \mathrm{mg} / \mathrm{kg} \mathrm{bw})$. After the duodenum, jejunum and ileum were removed from the rats, part of them was frozen in liquid nitrogen, and the rest were fixed in $4 \%$ buffered paraformaldehyde solution. All the operations were performed according to requirements of the standard protocol.

HE Staining. Tissues were cut into 3-4 mm thick sections, then stained with HE staining, and all the histologically stained slides were evaluated by high-power light microscopic examination (BX51; Olympus, Tokyo, Japan). Photos were taken at 5 central view angles and then the intestinal mucosal villus height and surface area $\left(S=2 \pi r^{*} h\right.$, $\mathrm{r}$ means the villous width, $\mathrm{h}$ means villous height) were calculated by IMAGE-PRO-PLUS.

ELISA assay. The levels of IL-6 and TNF- $\partial$ in the intestinum tenue were detected by enzyme-linked immunosorbent assay (ELISA). First, the kit was taken out of the refrigeration environment, coordinated for 30 min to room temperature, and then the working solution was prepared. Each well was supplemented with $50 \mathrm{~mL}$ of sample dilution, $50 \mu \mathrm{L}$ of standard and $50 \mu \mathrm{L}$ of testing sample, and incubated at $37^{\circ} \mathrm{C}$ for 2 hours, followed by adding washing buffer to every well, keeping it still for 30 $\mathrm{s}$, and then draining each well, which was repeated 6 times, and finally each well was dried by pat. Next, $100 \mu \mathrm{L}$ of HRP-Conjugate reagent was added to each well, except for the blank well, and incubated at $37^{\circ} \mathrm{C}$ for $45 \mathrm{~min}$. After washing each well 6 times, $100 \mu \mathrm{L}$ of TMB was added into each well, followed by $20 \mathrm{~min}$ incubation at $37^{\circ} \mathrm{C}$ in the dark, and then the addition of $100 \mu \mathrm{L}$ of stop solution to each well to stop the reaction. Within $15 \mathrm{~min}$, the absorbance/optical density (OD) at $450 \mathrm{~nm}$ was measured with a microtiter plate reader and the OD readings were used to draw the standard curves.

Immunohistochemistry. Tissues were fixed in $10 \%$ neutral buffered formalin, embedded in paraffin, and cut into $4-\mu \mathrm{m}$-thick sections. The sections were then postfixed with BSA confining liquid, and incubated for $20 \mathrm{~min}$ under ambient temperature. Then, each well was supplemented with rabbit anti-rat $\operatorname{Ig} \mathrm{A}$ (Bioss, Beijing, China), and incubated for $12 \mathrm{~h}$ at $4{ }^{\circ} \mathrm{C}$. Next, every well was washed 3 times with PBS for 2 min, followed by the addition of goat anti-rabbit IgG (ZSGB), incubation at $37^{\circ} \mathrm{C}$ for $20 \mathrm{~min}$, and washing each well 3 times with PBS for 2 min. After that, each well was supplemented with streptavidin-biotin-peroxidase complex (SABC) reagent, incubated at $37^{\circ} \mathrm{C}$ for $20 \mathrm{~min}$, and washed 4 times with PBS for 5 min. Finally, DAB coloration was performed to evaluate all the immunohistochemically stained sections by high-power light microscopic examination (BX51; Olympus, Tokyo, Japan).

Western Blot analysis. For Western-Blot analysis, proteins were extracted with RIPA (Beyotime) and their concentrations were measured by gel-electrophoretic separation. Briefly, 8\% SDS-PAGE was prepared according to the molecular weight of the proteins, and a piece of PVDF membrane (Millipore, IPVH00010) was cut according to the size of gel, followed by soaking the PVDF with 5\% TBST, and rocking gently for $2 \mathrm{~h}$. Next, the first appropriately diluted antibody was added into blocking buffer and incubated for $12 \mathrm{~h}$ at $4{ }^{\circ} \mathrm{C}$. The development was stopped by washing membrane 6 times with TBST for $5 \mathrm{~min}$. The bands on the membrane were checked by an enhanced chemiluminescence (ECL) detection system.

Statistical Analysis. Statistical analysis was performed using the Statistical Package for the Social Sciences (SPSS, v.17.0; SPSS, Chicago, IL, USA) and Graphpad Prism 5 software (Graphpad, San Diego, CA, USA). ANOVA and post hoc tests support the statistical validity of these conclusions at a statistical significance level of $\mathrm{p}<0.05$ and $\mathrm{p}<0.01$ which are regarded as highly statistically significant (Armstrong et al., 1997). 


\section{RESULTS}

Structural changes of intestinal villus. When compared with the control (saline) group, the visfatin group had a decrease in the villus height and width, indicating the villus tendency to atrophy. In the visfatin+LPS co-stimulated group, the villus height and width were decreased and tended to shrink after LPS injection when compared with LPS group (Table I (visfatin group) vs (control group), $\mathrm{p}<0.01$ in the duodenum, $\mathrm{p}<0.05$ in ileum; (visfatin+LPS costimulated group) vs (LPS group), $\mathrm{p}<0.01$ in the duodenum, $\mathrm{p}<0.05$ in jejunum and ileum). The crypt depth in visfatin group was lower than that of control group, while that in visfatin+LPS co-stimulated group was lower than that in LPS group $(\mathrm{p}<0.05)$.

According to data analysis, the visfatin group showed a more significant decrease in the intestinal villus area than the control group, and the LPS group was more significantly decreased than the visfatin+LPS co-stimulated group in terms of villus area (Figs. 1 and 2B, J (visfatin group) vs Fig. 2A, I (control group), $\mathrm{p}<0.01$ in the duodenum and ileum; Fig. 2D (visfatin+LPS co-stimulated group) vs Fig. 2C (LPS group), $\mathrm{p}<0.05$ in the duodenum).

Visfatin impacts inflammatory cytokines in small intestine of LPS-treated rats. The concentrations of inflammatory cytokines, IL-6 and TNF- $\partial$ were detected by ELISA. Compared with the control group, the visfatin group was found to have a significantly higher IL-6 concentration in duodenum (Fig. 3A, p<0.05). Additionally, the visfatin+LPS co-stimulated group showed a downward tendency in the level of IL-6 versus the LPS group, and the level of TNF- $\partial$ was significantly lower in the visfatin+LPS co-stimulated group than in the LPS group (Fig. 3B, p<0.05).

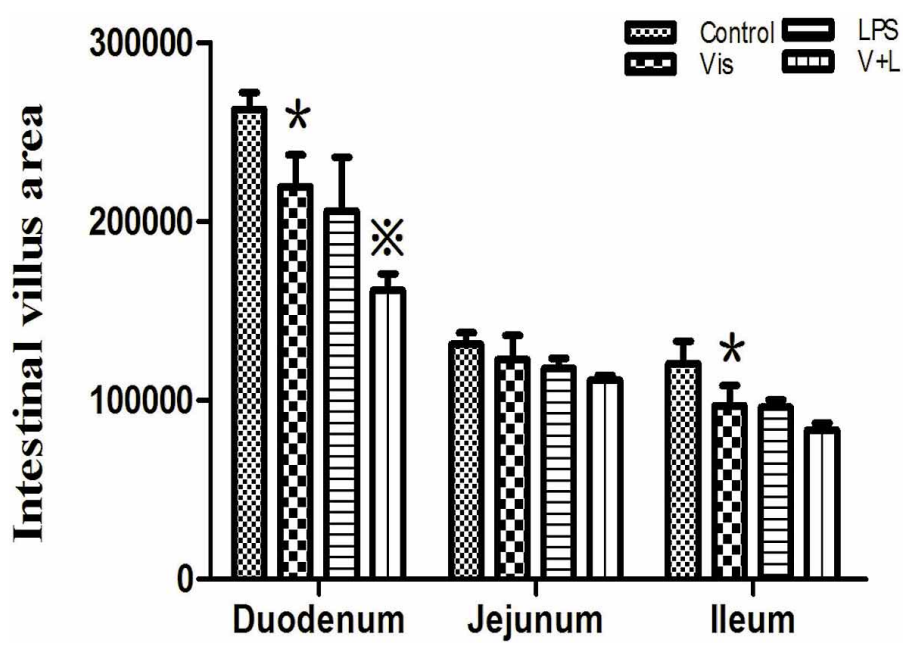

Fig. 1. The intestinal villus area of different experimental groups in duodenum, jejunum and ileum. *= indicates significant difference versus control group $(\mathrm{p}<0.05) ; * *=$ indicate significant difference versus LPS group $(\mathrm{p}<0.05)$.

Detection of immune-associated IgA-positive cells in small intestine. The immune-associated protein IgA was detected by immunohistochemistry, and the IgA-positive cells were brown in color. Compared with the control group, the visfatin group had a markedly larger amount of IgA-positive cells in duodenum (Fig. 4A, B, C and D) and ileum (Fig. 4I, J, K and L) ( $\mathrm{p}<0.05)$ and an extremely significantly higher amount in jejunum (Fig. 4E, F, G and H) $(p<0.01)$. Furthermore, the level of IgA positive cells in the visfatin+LPS co-stimulated group was higher than that in the visfatin group, but not significantly different from each other (Fig. 5).

\section{Changes in expression of protein IgA in small intestine. Western} blot analysis showed that the expression of protein $\operatorname{IgA}$ varied in all the tested groups. The visfatin group showed the highest expression of protein IgA among the fourgroups and it was significantly higher than that of the control group. Additionally,

Table I The effect of Visfatin on intestinal villus and fossae (Unit: mm).

\begin{tabular}{lccccc}
\hline \multirow{3}{*}{ Duodenum } & Group & Control & Visfatin & LPS & Visfatin+LPS \\
\cline { 2 - 6 } & Villus height & $491.93 \pm 38.48$ & $432.74 \pm 43.88 \mathrm{~A}$ & $427.06 \pm 35.48$ & $380.75 \pm 18.65 \mathrm{~B}$ \\
& Villus width & $166.32 \pm 27.14$ & $164.67 \pm 34.14 \mathrm{a}$ & $156.43 \pm 25.85$ & $148.86 \pm 27.08 \mathrm{~B}$ \\
\multirow{3}{*}{ Jejunum } & Crypt depth & $146.14 \pm 31.17$ & $111.54 \pm 9.76^{\mathrm{a}}$ & $107.18 \pm 22.09$ & $90.70 \pm 5.58 \mathrm{~b}$ \\
& Villus height & $338.27 \pm 31.29$ & $324.66 \pm 19.50$ & $320.11 \pm 36.37$ & $309.10 \pm 32.78$ \\
& Villus width & $125.53 \pm 21.32$ & $120.58 \pm 22.85$ & $116.79 \pm 24.22$ & $109.58 \pm 22.84 \mathrm{~b}$ \\
\multirow{2}{*}{ Ileum } & Crypt depth & $108.04 \pm 6.67$ & $103.73 \pm 36.26 \mathrm{a}$ & $112.13 \pm 30.35$ & $90.26 \pm 21.83$ \\
& Villus height & $285.78 \pm 11.74$ & $273.52 \pm 11.66 \mathrm{a}$ & $271.33 \pm 15.92$ & $254.63 \pm 20.08 \mathrm{~b}$ \\
& Villus width & $122.09 \pm 13.60$ & $113.07 \pm 18.91 \mathrm{a}$ & $112.58 \pm 11.37$ & $104.55 \pm 18.67$ \\
& Crypt depth & $122.72 \pm 8.57$ & $103.51 \pm 25.49 \mathrm{a}$ & $107.67 \pm 12.97$ & $113.02 \pm 32.39$ \\
\hline
\end{tabular}

Note: $\mathrm{A}=$ indicates highly significant difference versus control group $(\mathrm{p}<0.01) ; \mathrm{a}=$ indicates significant difference versus control group ( $<<0.05) . B=$ indicates highly significant difference compared with LPS group $(p<0.01) ; b=$ indicates significant difference versus LPS group $(\mathrm{p}<0.05)$. 
the visfatin+LPS co-stimulated group had higher expression of IgA than that of the LPS group, especially in jejunum
(Fig. 6B) and ileum (Fig. 6C), but the change was not obvious in duodenum (Fig. 6A).

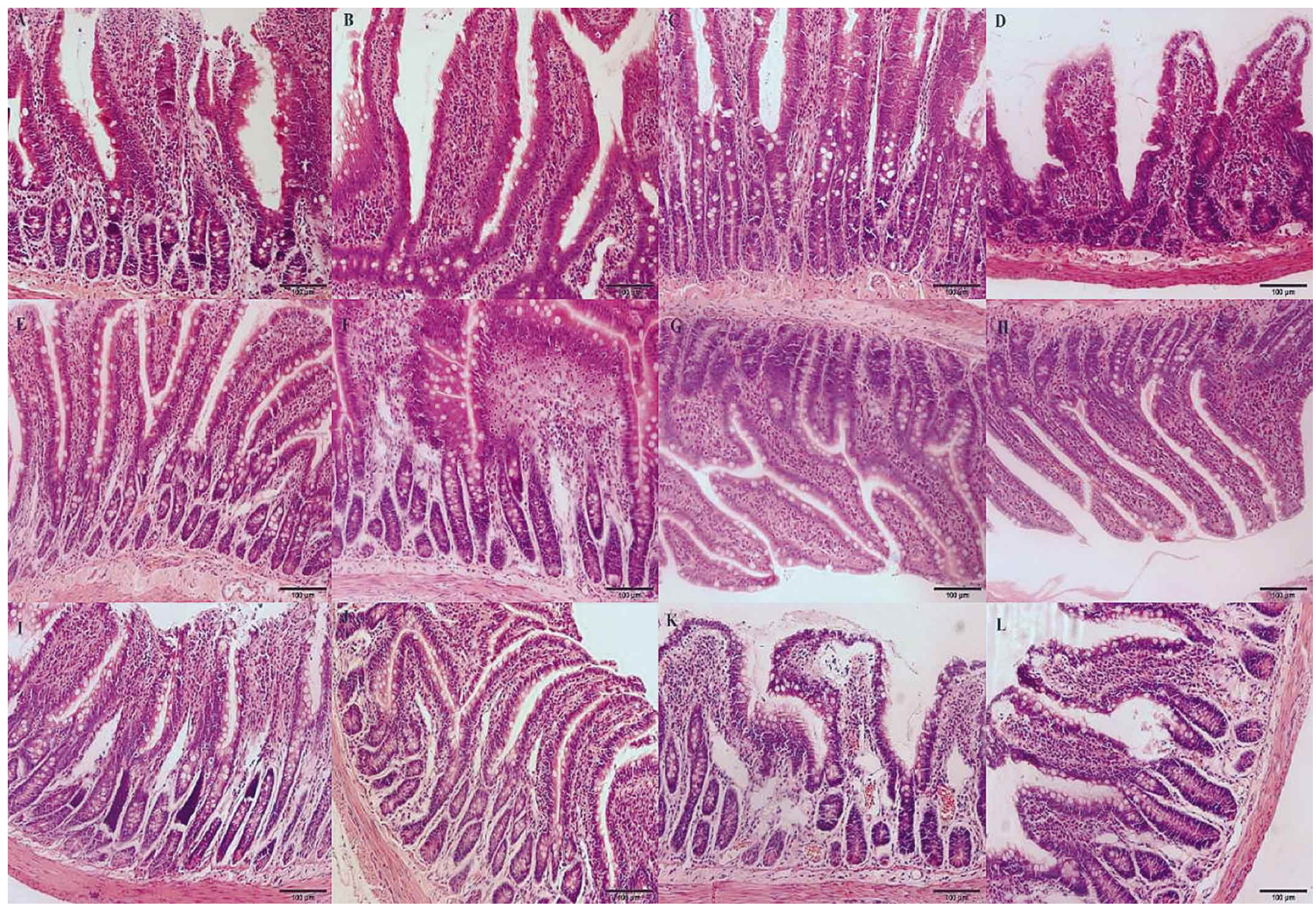

Fig. 2. The changes in villus structure of different experimental groups (10x40). In Duodenum, (A) Control group, (B) Visfatin group, (C) LPS group, (D) Visfatin+LPS co-stimulated group; in Jejunum (E) Control group, (F) Visfatin group, (G) LPS group, (H) Visfatin+LPS co-stimulated group; and in Ileum (I) Control group, (J) Visfatin group, (K) LPS group, (L) Visfatin+LPS co-stimulated group.
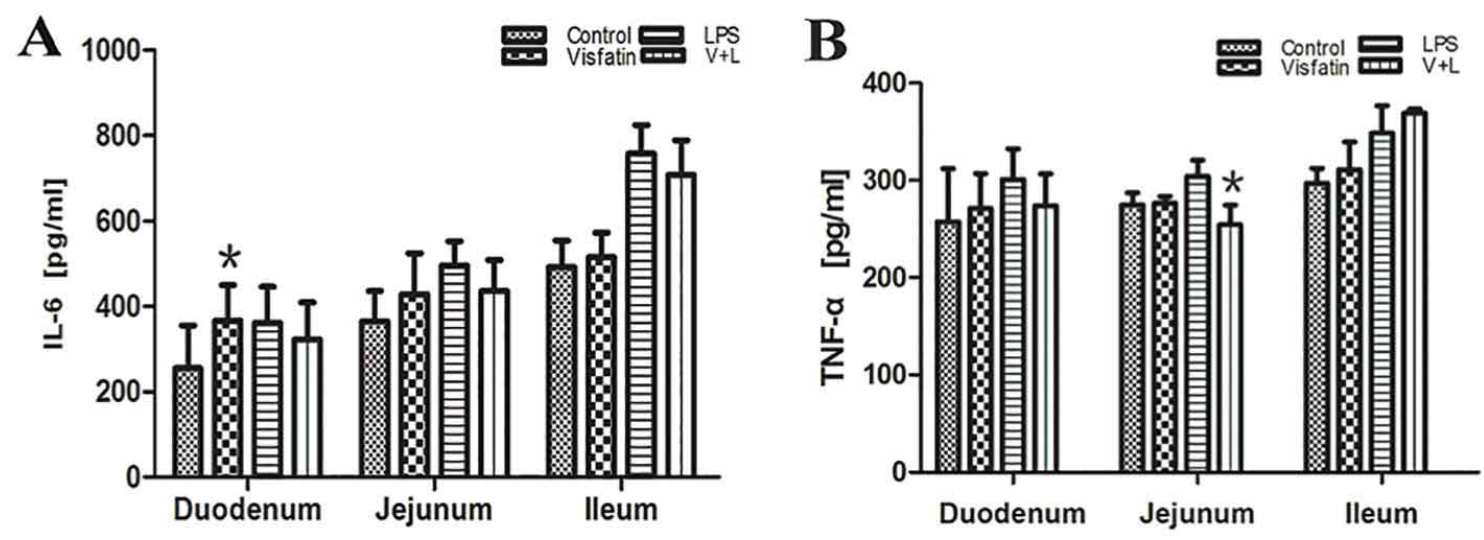

Fig. 3. The levels of IL-6 and TNF- $\partial$ in different experimental groups in duodenum, jejunum and ileum. a): *=indicates significant difference versus control group $(\mathrm{p}<0.05) . \mathrm{b}): *=$ indicates significant difference versus LPS group $(\mathrm{p}<0.05)$. IL-6 was higher in visfatin group in duodenum $(\mathrm{p}<0.05)$. The level of TNF- $\partial$ was significantly decreased in $\mathrm{V}+\mathrm{L}$ costimulated group versus LPS group $(\mathrm{p}<0.05)$. 


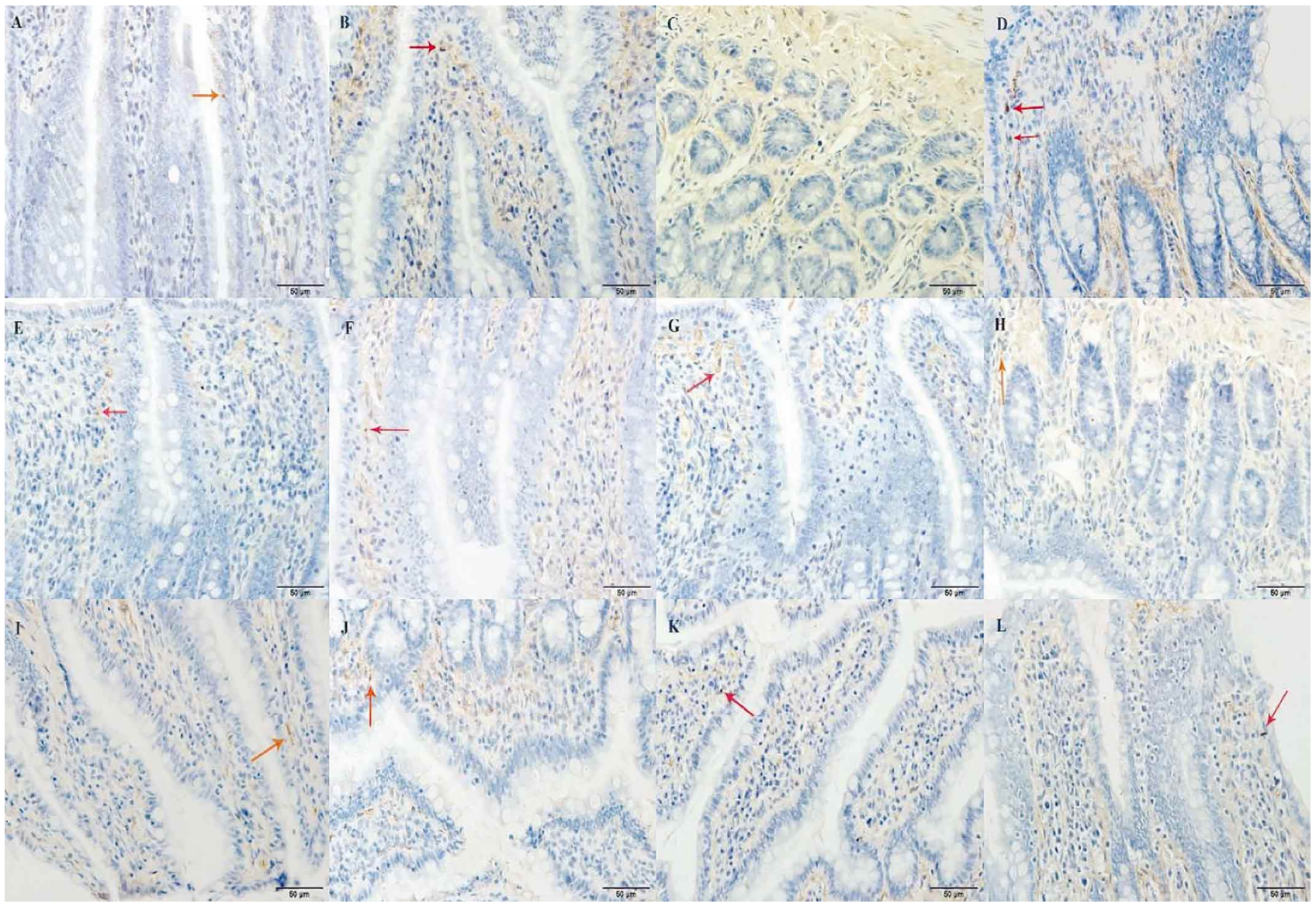

Fig. 4. The expression of IgA positive cells in different treatment groups (IHC, 10x40). The changes in expression of IgA positive cells of Duodenum in (A) Control group, (B) Visfatin group, (C) LPS group, (D) Visfatin+LPS co-stimulated group; of Jejunum in (E) Control group, (F) Visfatin group, (G) LPS group, (H) Visfatin+LPS co-stimulated group; and of Ileum in (I) Control group, (J) Visfatin group, (K) LPS group, (L) Visfatin+LPS co-stimulated group.

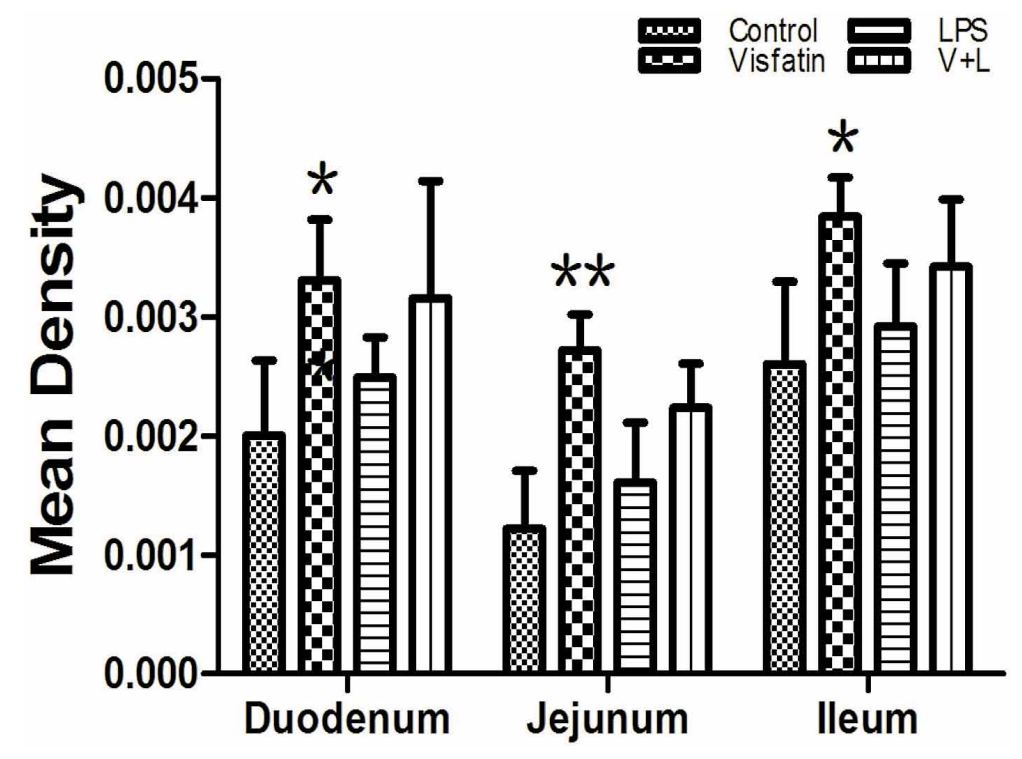

Fig. 5. The optical densities of IgA positive cells in different experimental groups in small intestine. $* *=$ indicates extremely significant difference versus control group $(\mathrm{p}<0.01) ;$ indicates significant difference versus control group $(\mathrm{p}<0.05)$. The amount of IgA-positive cells in visfatin group versus control group was markedly higher in the duodenum and ileum $(\mathrm{p}<0.05)$, and extremely significantly higher in jejunum $(\mathrm{p}<0.01)$. 

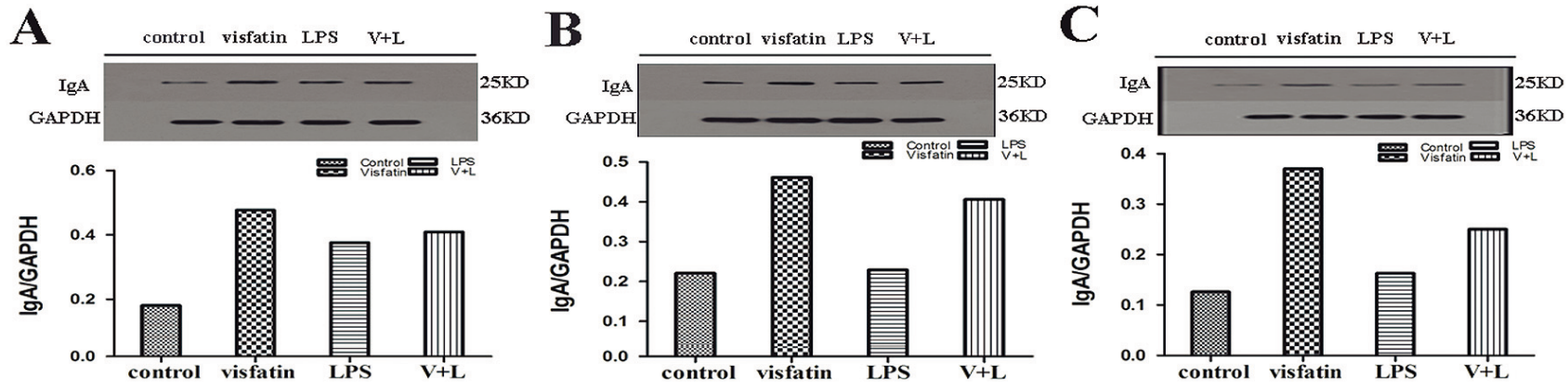

Fig. 6. The changes of IgA expression in intestinal mucosa by Western Blot analysis. The visfatin+LPS co-stimulated group had higher expression of IgA than LPS group. (A) Duodenum; (B) Jejunum and (C) Ileum. The expression of protein IgA in visfatin group was the highest among the four groups, and the level of protein IgA distinctly increased versus control group.

\section{DISCUSSION}

The effect of visfatin on the structure of the intestine in the LPS-treated rats. Intestinal barrier function is mainly decided by the intestinal mucosal barrier. The structural integrity of the intestinal mucosal epithelium has a close relationship with the body's immune function, specially villous height, width, thickness and area, which are the important indicators of intestinal digestion and absorption function (Fukuhara et al., 2005; Lin et al., 2014; Samal et al., 1994). Under stress conditions, the body's bowel is vulnerable to infection, leading to tissue variations, with the most obvious changes in intestine, such as atrophic villus and hyperplastic crypt.

In the present study, compared with the control group, the visfatin group had a significant tendency to atrophy in villus height and width $(\mathrm{p}<0.05)$. The results indicated that visfatin stimulated the body as an exogenous substance and accelerated the dissolution of the intestine villus, implying that visfatin may accelerate cell apoptosis. Compared with the LPS group, the villus height and width were also markedly decreased in the visfatin+LPS co-stimulated group ( $\mathrm{p}<0.01)$, suggesting that the damage to the intestinal villus was perhaps caused by the synergy between visfatin and LPS, or visfatin could regulate the changes induced by LPS. However, due to the short time of visfatin-treatment, the effect was not obvious, and the mechanism underlying these different responses remains to be elucidated in the further study.

The impact of visfatin inflammatory cytokines on the small intestine of LPS-treated rats. Pro-inflammatory factors are involved in the immune response. IL-1ß, IL-6 and TNF- $\partial$ are the pro-inflammatory mediators, which are produced by the macrophage and play an important role in innate and adaptive immunity. Visfatin has been reported to be associated with TNF- $\partial$, IL-6, IL-1ß, and IL-1 receptor in peripheral blood cell membranes (Didierlaurent et al.; Ognjanovic \& Bryant-Greenwood; Moschen et al., 2010; Rothe et al., 1993). In the previous study, the findings suggest that the level of glucose significantly increased after $30 \mathrm{~min}$ in acute management by recombinant visfatin, but recovered to the normal level quickly 60 min later (Fukuhara et al.; Moschen et al., 2007; Trayhurn \& Beattie, 2001). Alexander has reported that the level of IL-6 conspicuously increased $15 \mathrm{~h}$ after treatment, but dropped to the normal level rapidly at $20 \mathrm{~h}$ (Dinarello, 2004; R Moschen et al., 2010; Romacho et al., 2013). These results indicated that the short half-life of visfatin might be influenced in the animal serum.

In the present study, the levels of pro-inflammatory factors, IL- 6 and TNF- $\partial$ were found to be elevated in the visfatin-treated group versus the control group, and were obviously different in the duodenum. The negative correlation between the TNF- $\partial$ in the blood and visfatin indicated that visfatin plays an anti-inflammatory role. Additionally, the levels of TNF- $\partial$ and IL- 6 were decreased in the visfatin+LPS co-stimulated group versus the LPS group, and the decrease was statistically significant in jejunum. The aforementioned results showed that visfatin regulated inflammatory cytokines on lipopolysaccharide stimulation, reduced the release of inflammatory cytokines and strengthened the cellular immune function during immune stress. Furthermore, visfatin inhibited the expression of TNF- $\partial$ and IL-6 in the intestine, indicating that visfatin plays an important role in inflammatory response in LPStreated rats by regulating the expression of TNF- $\partial$ and IL-6. 
The influence of visfatin on the expression of IgA in the intestine of the LPS-treated rats. $\operatorname{Ig} \mathrm{A}$ is an antibody transporter expressed on the basolateral surface of epithelial cells and provides mucosal immune protection due to its ability to interact with the polymeric Ig receptor (pIgR). IgA dimer expressed the highest levels in the intestinal secretions (Brandtzaeg et al., 1991; Gallorini et al., 2014). In the present study, the immunohistochemistry and western blot analysis results indicated that the level of $\operatorname{IgA}$ in the visfatin group was markedly higher than that in the control group in duodenum, jejunum and ileum, suggesting that, under normal circumstances, visfatin stimulated the body as an exogenous substance, further enhancing the secretion of IgA. IgA is not an inflammatory cytokine, but it plays an important role in intestinal mucosal immunity system by mediating humoral immunity. $\operatorname{IgA}$ is regulated by the nervous system, endocrine system and immune system, but IgA is released by plasma cells and has a vital role in intestinal mucosa immunity (Brandtzaeg, 2010; Pinto et al., 2013).

In the present study, visfatin promoted the expression of IgA in the visfatin+LPS co-stimulated group versus the LPS group, and the increase was significant in jejunum and ileum, but not in duodenum. We speculated that visfatin may have an antagonistic effect on LPS-treated rats by preventing further inflammatory reaction through promoting the expression of IgA. Taken together, it suggested that visfatin has enhanced the humoral immune response during immune stress.

\section{CONCLUSIONS}

As an exogenous substance, visfatin is involved in inflammatory responses by modulating the expression of $\operatorname{Ig} \mathrm{A}$ and inflammatory cytokines: up-regulating the inflammatory cytokines IL- 6 and TNF- $\partial$ in rat intestine and downregulating the inflammatory cytokines of IL- 6 and TNF- $\partial$ in response to LPS treatment.

Under immune stress conditions, visfatin exerts an antagonistic effect as an exogenous antigen by regulating the expression of IgA. Visfatin promotes the expression of $\operatorname{IgA}$ in rat intestine and further enhances the $\operatorname{IgA}$ secretion in response to LPS challenge.

\section{ACKNOWLEDGEMENTS}

This research work was supported by a grant from the National Natural Science Foundation of China under grant agreement $\left(\mathrm{N}^{\circ} 31101776\right)$ and National College Student Creative Enterprising Training ( $\left.{ }^{\circ} 201210504002\right)$.
ZHOU, Y.; CUI, L.; YUN, H.; XIO, K.; KAHN, F. A.; GUO, L.; YANG, Z. \& SONG, H. Efecto de la visfatina sobre la estructura y los niveles de inmunidad en el intestino delgado de ratas inducidas por lipopolisacáridos. Int. J. Morphol., 33(4):1502-1509, 2015 .

RESUMEN: Este estudio investigó los efectos de la visfatina sobre la estructura y los niveles de inmunidad en el intestino delgado de ratas inducidas por lipopolisacáridos (LPS). Cuarenta ratas Wistar se dividieron aleatoriamente e igualmente en cuatro grupos: solución salina (control), vistafin, LPS y visfatina + LPS co-estimuladas. Las funciones de la visfatina en la inmunidad de la mucosa intestinal se investigaron mediante el examen de variación de la estructura del tejido, la inflamación y las proteínas relacionadas con la inmunidad en el intestino de ratas estresadas inmunológicamente; usando tinción HE, ELISA, inmunohistoquímica y Western Blot. Los resultados mostraron que, en comparación con el grupo control, el grupo tratado con visfatina presentó una disminución en la altura y ancho de las vellosidades intestinales, y un aumento significativo en los niveles de IL-6 y TNF- $\partial$, así como inmunoglobulina A (IgA células positivas). Además, al comparar este grupo con el grupo tratado con LPS- el grupo visfatina + LPS co-estimulado mostró una disminución en la altura y ancho de las vellosidades, así como en los niveles de IL-6 y TNF- $\partial$, y un aumento en los niveles de IgA, lo que implica reducción de una respuesta a la inyección LPS. Todos los resultados sugieren que, en condiciones fisiológicas normales, la visfatina perturba la homeostasis del cuerpo y provoca la atrofia de las vellosidades intestinales mediante el aumento de la expresión de IgA. Mientras que bajo condiciones de la respuesta inmune, LPS actúa como un antígeno exógeno para promover visfatina contra la inflamación inducida por LPS por la disminución de la expresión de IgA. En condiciones de estrés inmunológico, la visfatina como estímulo exógeno promueve la respuesta inmune mediante la regulación de los niveles de proteína de IL-6, TNF-ð e IgA.

PALABRAS CLAVE: Visfatina; Mucosa intestinal; Ratas LPS-inducidas; IgA; Factor de inflamación.

\section{REFERENCES}

Armstrong, R. C.; Aja, T. J.; Hoang, K. D.; Gaur, S.; Bai, X.; Alnemri, E. S.; Litwack, G.; Karanewsky, D. S.; Fritz, L. C. \& Tomaselli, K. J. Activation of the CED3/ICE-related protease CPP32 in cerebellar granule neurons undergoing apoptosis but not necrosis. J. Neurosci., 17(2):553-62, 1997.

Brandtzaeg, P. The mucosal immune system and its integration with the mammary glands. J. Pediatr., 156(2 Suppl.):S8-15, 2010.

Brandtzaeg, P.; Nilssen, D. E.; Rognum, T. O. \& Thrane, P. S. Ontogeny of the mucosal immune system and $\operatorname{IgA}$ deficiency. Gastroenterol. Clin. North Am., 20(3):397-439, 1991.

Brentano, F.; Schorr, O.; Ospelt, C.; Stanczyk, J.; Gay, R. E.; Gay, S. \& Kyburz, D. Pre-B cell colony-enhancing factor/visfatin, a new marker of inflammation in rheumatoid arthritis with 
proinflammatory and matrix-degrading activities. Arthritis Rheum., 56(9):2829-39, 2007.

Didierlaurent, A.; Sirard, J. C.; Kraehenbuhl, J. P. \& Neutra, M. R. How the gut senses its content. Cell. Microbiol., 4(2):61-72, 2002.

Dinarello, C. A. Unraveling the NALP-3/IL-1beta inflammasome: a big lesson from a small mutation. Immunity, 20(3):243-4, 2004.

Eker, S.; Ayaz, L.; Tamer, L. \& Ulubas, B. Leptin, visfatin, insulin resistance, and body composition change in chronic obstructive pulmonary disease. Scand. J. Clin. Lab. Invest., 70(1):40-4, 2010.

Fukuhara, A.; Matsuda, M.; Nishizawa, M.; Segawa, K.; Tanaka, M.; Kishimoto, K.; Matsuki, Y.; Murakami, M.; Ichisaka, T.; Murakami, H.; Watanabe, E.; Takagi, T.; Akiyoshi, M.; Ohtsubo, T.; Kihara, S.; Yamashita, S.; Makishima, M.; Funahashi, T.; Yamanaka, S.; Hiramatsu, R.; Matsuzawa, Y. \& Shimomura, I. Visfatin: a protein secreted by visceral fat that mimics the effects of insulin. Science, 307(5708):426-30, 2005.

Gallorini, S.; Taccone, M.; Bonci, A.; Nardelli, F.; Casini, D.; Bonificio, A.; Kommareddy, S.; Bertholet, S.; O’Hagan, D. T. $\&$ Baudner, B. C. Sublingual immunization with a subunit influenza vaccine elicits comparable systemic immune response as intramuscular immunization, but also induces local IgA and TH17 responses. Vaccine, 32(20):2382-8, 2014.

Gao, W.; Mao, Q.; Feng, A. W.; Sun, H. M.; Sun, W. K.; Lu, X.; Su, X. \& Shi, Y. Inhibition of pre-B cell colony-enhancing factor attenuates inflammation and apoptosis induced by pandemic H1N1 2009 in lung endothelium. Respir. Physiol. Neurobiol., 178(2):235-41, 2011.

Goujon, E.; Parnet, P.; Layé, S.; Combe, C. \& Dantzer, R. Adrenalectomy enhances pro-inflammatory cytokines gene expression, in the spleen, pituitary and brain of mice in response to lipopolysaccharide. Brain Res. Mol. Brain Res., 36(1):5362, 1996

Lin, M.; Du, L.; Brandtzaeg, P. \& Pan-Hammarström, Q. IgA subclass switch recombination in human mucosal and systemic immune compartments. Mucosal Immunol., 7(3):511-20, 2014.

MacDonald, T. T. The mucosal immune system. Parasite Immunol., 25(5):235-46, 2003.

Moschen, A. R.; Gerner, R. R. \& Tilg, H. Pre-B cell colony enhancing factor/NAMPT/visfatin in inflammation and obesity-related disorders. Curr. Pharm. Des., 16(17):1913-20, 2010 .

Moschen, A. R.; Kaser, A.; Enrich, B.; Mosheimer, B.; Theurl, M.; Niederegger, H. \& Tilg, H. Visfatin, an adipocytokine with proinflammatory and immunomodulating properties. $J$. Immunol., 178(3):1748-58, 2007.

Ognjanovic, S. \& Bryant-Greenwood, G. D. Pre-B-cell colonyenhancing factor, a novel cytokine of human fetal membranes. Am. J. Obstet. Gynecol., 187(4):1051-8, 2002.
Pinto, D.; Montani, E.; Bolli, M.; Garavaglia, G.; Sallusto, F.; Lanzavecchia, A. \& Jarrossay, D. A functional BCR in human IgA and IgM plasma cells. Blood, 121(20):4110-4, 2013.

Romacho, T.; Villalobos, L. A.; Cercas, E.; Carraro, R.; SánchezFerrer, C. F. \& Peiró, C. Visfatin as a novel mediator released by inflamed human endothelial cells. PloS One, 8(10):e78283, 2013.

Rothe, J.; Lesslauer, W.; Lötscher, H.; Lang, Y.; Koebel, P.; Köntgen, F.; Althage, A.; Zinkernagel, R.; Steinmetz, M. \& Bluethmann, $\mathrm{H}$. Mice lacking the tumour necrosis factor receptor 1 are resistant to TNF-mediated toxicity but highly susceptible to infection by Listeria monocytogenes. Nature, 364(6440):798-802, 1993.

Samal, B.; Sun, Y.; Stearns, G.; Xie, C.; Suggs, S. \& McNiece, I. Cloning and characterization of the cDNA encoding a novel human pre-B-cell colony-enhancing factor. Mol. Cell. Biol., 14(2):1431-7, 1994.

Shaykhiev, R. \& Bals, R. Interactions between epithelial cells and leukocytes in immunity and tissue homeostasis. J. Leukoc. Biol., 82(1):1-15, 2007.

Skoczen, S.; Tomasik, P. J.; Gozdzik, J.; Fijorek, K.; KrasowskaKwiecien, A.; Wiecha, O.; Czogala, W.; Dluzniewska, A.; Sztefko, K.; Starzyk, J. \& Siedlar, M. Visfatin concentrations in children with leukemia before and after stem cell transplantation. Exp. Hematol., 42(4):252-60, 2014.

Stephens, J. M. \& Vidal-Puig, A. J. An update on visfatin/pre-B cell colony-enhancing factor, an ubiquitously expressed, illusive cytokine that is regulated in obesity. Curr. Opin. Lipidol., 17(2):128-31, 2006.

Trayhurn, P. \& Beattie, J. H. Physiological role of adipose tissue: white adipose tissue as an endocrine and secretory organ. Proc. Nutr. Soc., 60(3):329-39, 2001.

\section{Correspondence to:}

Hui Song

College of Veterinary Medicine

Huazhong Agricultural University

Wuhan 430070

Hubei

PR CHINA

\section{Email: 476628473@qq.com songh2007@mail.hzau.edu.cn songh1206@aliyun.com}

Received: 06-06-2015

Accepted: 21-09-2015 